Article

\title{
Evaluating Communities' Willingness to Participate in Ecosystem Conservation in Southeast Tibetan Nature Reserves, China
}

\author{
Lingxia $X u^{1}$, Wanyun $X u^{1}$, Chao Jiang ${ }^{2}$, Huxuan Dai ${ }^{1,3}$, Qiaoqi Sun ${ }^{1}$, Kun Cheng ${ }^{1, *}$, Chun-Hung Lee ${ }^{4} \mathbb{D}$, \\ Cheng Zong ${ }^{1}$ and Jianzhang $\mathrm{Ma}^{1}$
}

check for

updates

Citation: Xu, L.; Xu, W.; Jiang, C.;

Dai, H.; Sun, Q.; Cheng, K.; Lee,

C.-H.; Zong, C.; Ma, J. Evaluating

Communities' Willingness to

Participate in Ecosystem

Conservation in Southeast Tibetan

Nature Reserves, China. Land 2022,

11, 207. https://doi.org/10.3390/

land11020207

Academic Editor:

Alexandru-Ionut Petrisor

Received: 15 December 2021

Accepted: 26 January 2022

Published: 28 January 2022

Publisher's Note: MDPI stays neutral with regard to jurisdictional claims in published maps and institutional affiliations.

Copyright: (C) 2022 by the authors. Licensee MDPI, Basel, Switzerland. This article is an open access article distributed under the terms and conditions of the Creative Commons Attribution (CC BY) license (https:// creativecommons.org/licenses/by/ $4.0 /)$.
1 College of Wildlife and Protected Areas, Northeast Forestry University, Harbin 150040, China; xulingxia@nefu.edu.cn (L.X.); xwy@nefu.edu.cn (W.X.); Huxuan.Dai21@student.xjtlu.edu.cn (H.D.); qiaoqi.sun@nefu.edu.cn (Q.S.); moredonkey@163.com (C.Z.); jianzhangma@163.com (J.M.)

2 Qixinghe National Nature Reserve Administration, Shuangyashan 155600, China; jiangz891126@163.com

3 Department of Health and Environmental Sciences, Xi'an Jiaotong-Liverpool University, Suzhou 215000, China

4 Department of Natural Resources and Environmental Studies, School of Environmental Studies, National Dong Hwa University, Hualien 97401, Taiwan; chlee@gms.ndhu.edu.tw

* Correspondence: chengkun@nefu.edu.cn

\begin{abstract}
Southeast Tibet is significant in maintaining key ecological functions and providing irreplaceable ecosystem services but is also extremely vulnerable and susceptible to the impacts of human activities. Understanding the attitudes of local residents toward ecosystem conservation is considered essential for nature resource management. We therefore aimed to conduct an evaluation framework under hypothetical scenarios to measure communities' willingness to participate in ecosystem conservation using the contingent valuation method (CVM). Second, this study determined the underlying factors that might affect local's willingness to participate and then compared the willingness to pay (WTP) and willingness to work (WTW) for different types of nature reserves. We found that income, education, community attachment, and acceptance of a payment scheme are significant factors determining the average amount that residents are willing to pay for ecosystem conservation, while their income, acceptance of a work scheme, and education are significant factors influencing the average service time that residents are willing to devote to work. Our results revealed that community residents have considerable willingness to participate in ecosystem conservation, which points not only to the great value attached to the ecosystem service function of Southeast Tibet nature but also suggests that people's willingness to participate is influenced by a conglomeration of socio-economic characteristics and their previous experience. The information herein can be used to implement conservation planning that involves community co-management and policymaking for sustainable development and will be beneficial to the dynamic conservation and adaptive management of Tibetan nature reserves.
\end{abstract}

Keywords: community participation; ecosystem conservation; economic evaluation; types of nature reserves; southeast Tibet

\section{Introduction}

\subsection{Community Participation in Ecosystem Conservation}

Protected areas are critical in preserving biodiversity and maintaining high ecosystem services [1,2]. As the primary form of protected areas in China, nature reserves (NRs) play a leading role in in situ conservation of flora and fauna, decision-making, and constitute an important element of sustainable development [3-5]. By the end of 2017, there were 2750 NRs in China, with a total area of 147.17 million hectares $\left(\mathrm{hm}^{2}\right)$, covering $14.86 \%$ of the country's land surface [6]. As one of the world's 34 biodiversity hot spots, southeast Tibet is significant in maintaining key ecological functions and providing irreplaceable 
ecosystem services [7]. However, ecosystems in southeast Tibet are extremely vulnerable and susceptible to both the impacts of human activities and natural disasters, to the extent that even a minor disturbance may cause severe environmental degradation, which can be permanent $[4,8,9]$. To protect the fragile region and key ecosystems, 47 various types of nature reserves were established in Tibet, covering a total area of $4.1 \times 10^{7} \mathrm{hm}^{2}$ and $34.4 \%$ of Tibet's territory areas by the year 2018 [10].

Establishing nature reserves has proved to be a key strategy for mitigating the loss of biodiversity and ecosystem degradation, and their efficacy lies largely in prohibiting the overuse of resources, such as banning tree harvesting, restricting grazing, and prohibiting cultivation in forests and grassland areas [11-13]. However, these restrictions on human activities often adversely affect the livelihoods of local residents by reducing their income [13]. In this context, local residents' attitudes to conservation policies are particularly important. Local communities, due to their geographical convenience, are widely acknowledged for their role in aiding NR management. This is particularly salient for achieving regional or local sustainable development goals [14,15] for ecosystem services and human well-being (i.e., the aspects of environment, culture, and the economy) [16-19], highlighting the need to enhance the tangible and intangible values of the aforementioned policies through a systematic analysis that takes into account communities' participation and efforts [19].

Integrating community participation with local peoples' attitudes and behavior through a systematic assessment can bolster the effectiveness of management aimed at ecosystem conservation in the future and is especially helpful for supporting communities' participation [16]. Understanding communities' attitudes is a key issue for conservation and management of protected areas, particularly from the standpoint of sustainable ecosystem development [18]. Moreover, fostering positive attitudes in local communities can be a key determinant of the success of sustainable development programs, which are long-term processes with both financial and non-financial effects on rural development [17]. Furthermore, policy makers also have to consider the effects of location and size to ensure the effectiveness of ecosystem conservation [19]. In many cases, local communities stand to gain the most from ecosystem services provided by healthy ecosystems [20]. It follows that if local communities are heavily dependent on activities that meet their subsistence needs but have a negative attitude toward ecosystem conservation, natural resource management and protection will be more challenging [14,21].

Therefore, quantifying the attitudes toward ecosystem conservation among local communities can assess the success of current conservation goals and actions and can also be used to inform and guide future practices. Thus, it is important to develop and implement suitable evaluation frameworks to assess communities' willingness to participate in ecosystem conservation in nature reserves.

\subsection{The Evaluation of Ecosystem Conservation under the Contingent Valuation Method}

Non-market evaluation is a tool that shows the monetary values of natural resources and ecosystem services measured in monetary terms [22-25]. Among mainstream methods, the contingent valuation method (CVM) is widely recognized for attaching financial values to the goods and services associated with ecosystem services [23,24], with its intrinsic ability to reveal individuals' preferences based on their willingness to pay (WTP) or willingness to work (WTW) for hypothetical scenarios [24,26] being especially helpful. The CVM is usually used in conjunction with questionnaires to estimate local communities' willingness to participate in ecosystem conservation under hypothetical market or other simulation contexts [22,24-26]. Local currency is the conventional unit of value used to assess stakeholder perspectives on ecological and environmental economics in CVM questions, owing to the flexibility this approach affords and its broad applicability across a range of feasible issues [22,27]. In practice, however, WTP is not a promising measure in the majority of developing countries, where household income is generally low and subsistence economies prevail [28]. In such cases, residents' WTP may be restricted by a household's ability to reduce its consumption of other goods to pay for the environmental good under valua- 
tion [29]. One suggestion to resolve this problem is to use non-monetary contribution as a proxy payment vehicle for estimating the factors linking WTP or WTW with ecosystem conservation and evaluating the welfare effects among hypothetical scenarios [22-27,30]. Starting from the work of Swallow and Woudyalew (1994) [31], labor or working time contributions as unit of measurement have been gaining importance in CVM studies in developing countries around the world [30,32]. Thus, the CVM is amenable to the use of WTW contributions, and it is an acceptable measure to use community members' willingness to contribute their time, rather than contribute money, to ecosystem conservation [24].

Previous environmental studies using the CVM framework have focused on tourism and festival events, marine protected areas, coastal areas, and terrestrial areas, and have evaluated the non-use values and conservation values attached to ecosystem services [22,31]. However, systematic evaluations of community preferences, as expressed in locals' willingness to participate in ecosystem conservation in Tibet's nature reserves, are lacking in the literature. Moreover, there is a paucity of research into the factors affecting residents ${ }^{\prime}$ willingness to participate in ecosystem conservation in this context, especially in terms of comparing the welfare effects among different types of nature reserves (NRs). Therefore, in addition to the evaluation of residents' WTP, we also decided to incorporate WTW as an estimator of willingness to participate in ecosystem conservation in southeast Tibet. The application of WTW ensures that the evaluation of willingness to participate will no longer be determined solely by reliance on monetary contributions, which can effectively alleviate residents' sense of powerlessness regarding WTP due to them possessing limited cash resources [24,33]. The CVM can effectively resolve the problem of underestimation bias confounding WTP measurement, and local residents' willingness to participate can be seen as providing an objective reflection of the values they attach to hypothetical scenarios [34].

Given the importance of community residents to NR conservation, the aim of this study was to analyze the attitudes toward, and willingness to participate in, ecosystem conservation among residents of communities located in and adjacent to NRs in southeast Tibet. To this end, we decided to (1) investigate NR community residents' perceptions and willingness to participate in ecosystem conservation in southeast Tibet and uncover the reasons for their non-participation; (2) determine the underlying factors that might affect local's willingness to participate; and (3) compare the differential responses from respondents who reside in or adjacent to different types of NRs regarding their willingness to participate, community perception, and knowledge of conservation resources.

\section{Materials and Methods}

\subsection{Study Area}

Southeast Tibet is in the southern Himalayan region and lies in the alpine canyon area on both sides of the Yarlung Zangbo River. Tibet's landforms and geological structure are very complex, with its undulating terrain giving rise to wide variations in elevation (150-5000 $\mathrm{m}$ a.s.1). Tibet is located in a subtropical mountain climate zone and is affected by the southwest monsoon, with abundant rainfall owing to the influence of this weather pattern [35]. Because of the region's specific physical geography and climatic conditions, Southeast Tibet accounts for $80 \%$ of the total forest area $\left(1.47 \times 10^{7} \mathrm{hm}^{2}\right)$ in the Tibet Autonomous Region. Its dense forests maintain rich biodiversity and serve as wildlife shelters, in addition to constituting ecological barriers for national and international ecological security [2].

To investigate local communities' cognition and willingness to participate in ecosystem conservation, six representative NRs were selected in southeast Tibet. According to protection targets or conservation purposes, these six NRs can be categorized into three groups [36]: (1) Forest ecosystem NRs; (2) Wetland ecosystem NRs; and (3) Reserves for protecting wildlife (Figure 1, Table 1). 


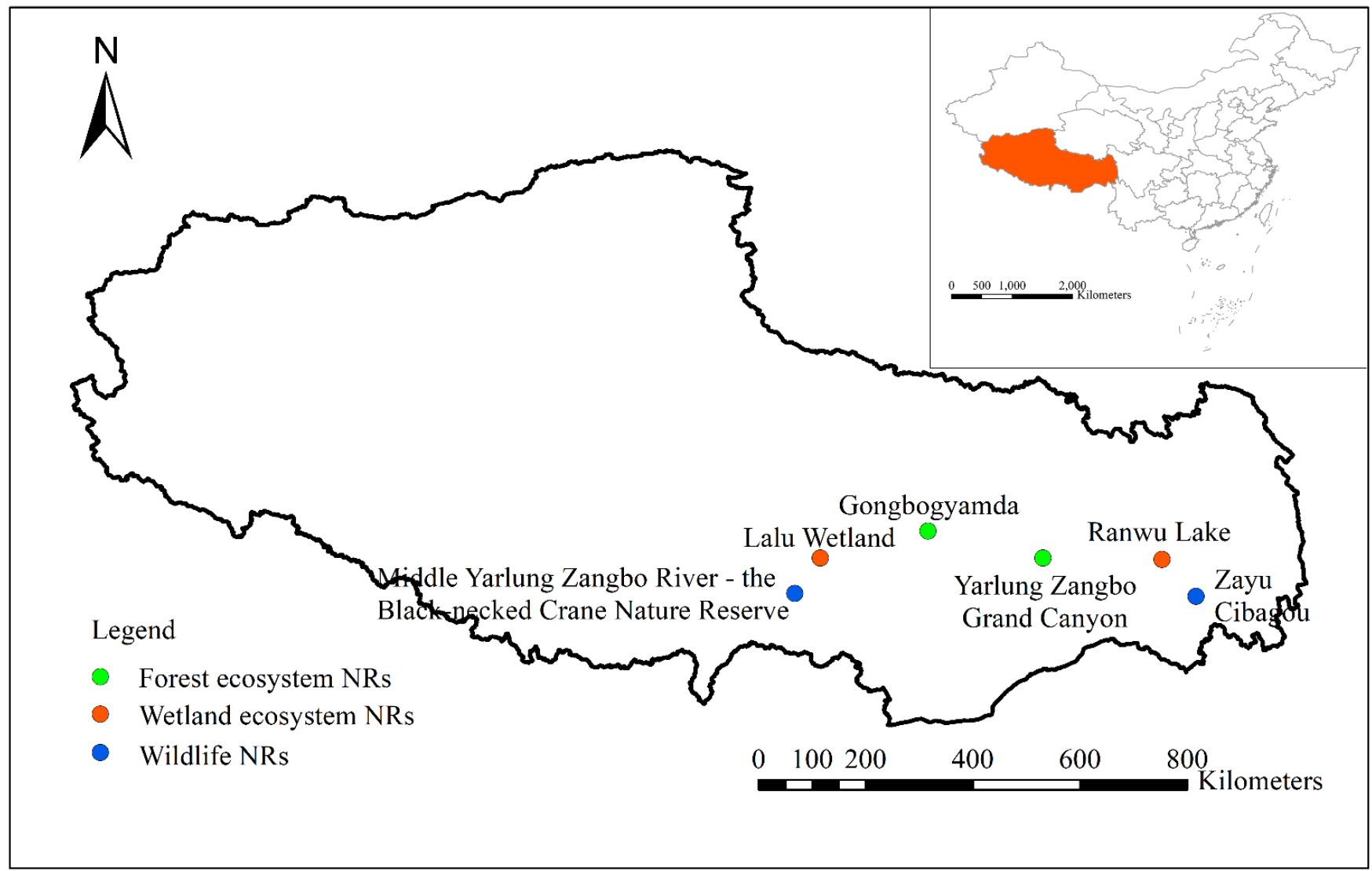

Figure 1. Locations of six nature reserves in southeast Tibet, that can be categorized into three types: green indicates forest ecosystem nature reserves, red indicates wetland ecosystem nature reserves, and blue indicates wildlife nature reserves.

Table 1. Nature reserve list and categories.

\begin{tabular}{|c|c|c|c|c|}
\hline $\begin{array}{l}\text { Nature Reserve } \\
\text { Categories }\end{array}$ & Name & $\begin{array}{l}\text { Area } \\
\left(\mathrm{hm}^{2}\right)\end{array}$ & $\begin{array}{l}\text { Protection } \\
\text { Objective }\end{array}$ & $\begin{array}{l}\text { Number of } \\
\text { Respondents }\end{array}$ \\
\hline \multirow[t]{2}{*}{ Forest ecosystem } & $\begin{array}{l}\text { Gongbogyamda } \\
\text { Provincial Nature } \\
\text { Reserve }\end{array}$ & $2,014,981$ & $\begin{array}{l}\text { Alpine mountain } \\
\text { forests }\end{array}$ & 259 \\
\hline & $\begin{array}{l}\text { Yarlung Zangbo Grand } \\
\text { Canyon National } \\
\text { Nature Reserve }\end{array}$ & 916,800 & $\begin{array}{l}\text { Mountain forest } \\
\text { ecosystem }\end{array}$ & 332 \\
\hline \multirow[t]{2}{*}{$\begin{array}{l}\text { Wetland } \\
\text { ecosystem }\end{array}$} & $\begin{array}{l}\text { Lalu Wetland National } \\
\text { Nature Reserve }\end{array}$ & 1220 & $\begin{array}{l}\text { Alpine wetland } \\
\text { ecosystem }\end{array}$ & 132 \\
\hline & $\begin{array}{l}\text { Ranwu Lake Provincial } \\
\text { Nature Reserve }\end{array}$ & 6978 & $\begin{array}{l}\text { Wetland } \\
\text { ecosystem }\end{array}$ & 82 \\
\hline \multirow[t]{2}{*}{$\begin{array}{l}\text { For protecting } \\
\text { wildlife }\end{array}$} & $\begin{array}{l}\text { Zayu Cibagou National } \\
\text { Nature Reserve }\end{array}$ & 101,400 & $\begin{array}{l}\text { Endangered } \\
\text { ungulates (e.g., } \\
\text { Budorcas } \\
\text { taxicolor) }\end{array}$ & 196 \\
\hline & $\begin{array}{l}\text { Middle Yarlung Zangbo } \\
\text { River-the Black-necked } \\
\text { Crane Nature Reserve }\end{array}$ & 614,350 & $\begin{array}{l}\text { Black-necked } \\
\text { cranes (Grus } \\
\text { nigricollis) }\end{array}$ & 129 \\
\hline
\end{tabular}

\subsection{Survey Implementation}

In order to receive valid responses in real time, we conducted face-to-face interviews. Drawing on knowledge about the characteristics of Tibetan communities and the previous 
literature $[33,37,38]$, the questionnaire comprised three sections with 19 questions in total (see Supplementary Materials).

The first section consisted of seven questions and was designed to reveal respondent's knowledge about the nature reserves and local wildlife species, their perceptions of community involvement in conservation, community attachment and satisfaction with the current protection status, and their acceptance to pay or work for ecosystem conservation.

The second section was intended to determine the respondents' willingness to participate in ecosystem conservation. We used the double-bounded dichotomous choice (DBDC) format to obtain the quantity of money and amount of time that local residents were willing to contribute, respectively. The initial bid values were determined by a questionnaire-based pilot study, whereby we distributed 53 open-ended prediction questionnaires and asked respondents to fill in the values of money and time they were willing to contribute to ecosystem conservation. The results thusly obtained were ranked in an ascending order, whereupon we selected the 24th, 42nd, 60th, and 78th percentiles of the dataset as the initial settings of bid values [39]. Therefore, WTP was initially determined at 75, 160, 500, and 750 Chinese Yuan (CNY) per year. The WTP would also be adjustable, depending upon residents' responses, and every respondent would be asked the same question(s) once again with the new sets of WTP [40]. For example, if the respondent's answer was "yes" to the first closed-ended question ("How much money would you consider contributing in order to avoid ecosystem function degradation?"), then the amount(s) would be doubled accordingly, such that the resultant "new" levels of payment were 150, 320, 1000, and 1500 CNY per year. In the alternative case, the initial amounts of WTP would be halved, giving amounts of $37.5,80,250$, and $375 \mathrm{CNY}$, correspondingly. Therefore, the four sets of WTP in our study were 75 (37.5/150), 160 (80/320), 500 (250/1000), and $750(375 / 1500)$ CNY. Similarly, the dynamic WTW scales were set at $4(2 / 8), 10(5 / 20), 24(12 / 48)$, and 36 $(18 / 72)$ hours per person per month. In this section of the investigation, we showed the respondents pictures of current undamaged healthy ecosystems and degraded ecosystems, and then a hypothetical market was constructed by enquiring of respondents, "How much money and time would you consider contributing in order to avoid ecosystem function degradation".

The last section included ten questions concerning the respondents' socio-economic characteristics, including gender, marital status, family size, age, education level, occupation, monthly income, participation in environment groups, working in nature reserves, and duration of residence in the community.

A formal investigation was initiated in 19 communities around six nature reserves from June to July 2016. Overall, 1130 respondents participated in the survey (Table 1), with an effective response rate of $100 \%$.

\subsection{Statistical Model}

In the present study, the respective estimated values of WTP and WTW using CVM double bounded dichotomous choice model theory are interval values, so the survival valuation function of the Weibull model was used to estimate each respondent's exact WTP and WTW [40,41]. Accordingly, the respondents' WTP and WTW can be calculated by the equations below:

$$
\begin{aligned}
& \log \left(W T P^{\chi}\right)=X_{i} \beta+\sigma \varepsilon^{\chi}, \chi=0.5 \\
& \log \left(W T W^{\chi}\right)=X_{i} \beta+\sigma \varepsilon^{\chi}, \chi=0.5
\end{aligned}
$$

where $W T^{\chi}\left(W T W^{\chi}\right)$ is the maximum price paid (working time provided) by a respondent, $X_{i}$ is the explanatory variable, $\beta$ is the parameter corresponding to the explanatory variable, $\sigma$ is a scale parameter and $\sigma>0, \varepsilon$ is an interference term that is independent of $X[42,43]$.

We used communities' WTP and WTW for ecosystem conservation as the dependent variables, and integrated social demographics (i.e., income, marital status, environmental group working, duration of community residence, working area, and location group of NRs), conservation attitudes, and behavior regarding ecosystem conservation (i.e., 
knowledge of conservation institutions, sense of place, and the perception of WTP and WTW) $[25,33,37,38,44-50]$, as the independent variables. We summarize the definitions of the explanatory variables and descriptive statistics in Table 2.

Table 2. Definition of the variables used and descriptive statistics for assessing the willingness to contribute to ecosystem conservation.

\begin{tabular}{|c|c|c|c|}
\hline Variable's Name & Definition & Mean & Std. Dev. \\
\hline Lnincome & $\begin{array}{l}\text { Respondent's monthly income in CNY, expressed } \\
\text { as the median value of the range, and then log } \\
\text { transferred }\end{array}$ & 8.10 & 0.016 \\
\hline Know & $\begin{array}{l}\text { Dummy variable, where } 1 \text { represents that the local } \\
\text { resident knows a conservation institution exists in } \\
\text { the village, while } 0 \text { indicates otherwise }\end{array}$ & 0.50 & 0.015 \\
\hline Sense & $\begin{array}{l}\text { Local resident's perception of willingness to reside } \\
\text { in their community for an extended period of time, } \\
\text { measured on the five-point Likert scale }\end{array}$ & 4.15 & 0.032 \\
\hline ATP & $\begin{array}{l}\text { Local resident's acceptance toward paying for } \\
\text { ecosystem conservation, measured by five-point } \\
\text { Likert scale }\end{array}$ & 3.34 & 0.033 \\
\hline$A T W$ & $\begin{array}{l}\text { Local resident's acceptance toward working for } \\
\text { ecosystem conservation, measured by five-point } \\
\text { Likert scale }\end{array}$ & 3.37 & 0.034 \\
\hline Marry & $\begin{array}{l}\text { Dummy variable, where } 1 \text { represents local residents } \\
\text { that are married, while } 0 \text { indicates otherwise }\end{array}$ & 0.71 & 0.014 \\
\hline$E d u$ & $\begin{array}{l}\text { Years of education: nine years for junior middle } \\
\text { school and below, three years for senior high school, } \\
\text { two years for junior college, four years for } \\
\text { university undergraduate degree, two years for } \\
\text { Master's degree or above }\end{array}$ & 11.21 & 0.082 \\
\hline Group & $\begin{array}{l}\text { Dummy variable, where } 1 \text { represents local residents } \\
\text { have joined an environmental group, while } 0 \\
\text { indicates otherwise }\end{array}$ & 0.116 & 0.010 \\
\hline Duration & $\begin{array}{l}\text { The duration of a local resident's community } \\
\text { residence, in years }\end{array}$ & 19.88 & 0.482 \\
\hline Workp & $\begin{array}{l}\text { Dummy variable, where } 1 \text { represents local residents } \\
\text { worked in the NRs, while } 0 \text { indicates otherwise } \\
\text { Dummy variable, where } 1 \text { represents local residents }\end{array}$ & 0.119 & 0.010 \\
\hline Location1 & $\begin{array}{l}\text { lived near the forest ecosystem nature reserve, } \\
\text { while } 0 \text { indicates otherwise }\end{array}$ & 0.52 & 0.015 \\
\hline Location 2 & $\begin{array}{l}\text { Dummy variable, where } 1 \text { represents local residents } \\
\text { lived near the wildlife nature reserve, while } 0 \\
\text { indicates otherwise }\end{array}$ & 0.29 & 0.013 \\
\hline
\end{tabular}

The advantages of measuring welfare by median are that it eliminates extreme observations and has above mean sensitivity regarding the follow-up responses when comparing with the confidence interval for the DBDC [51,52]. For these reasons, the median was adopted to represent the mean WTP and WTW for Tibetan ecosystem conservation. Maximum likelihood estimation was used to calculate the upper and lower limits of how much money and time residents were willing to contribute, at a 95\% confidence level.

Model estimations were conducted using the statistical software SAS 8.1. A one-way ANOVA test and independent sample T test were used to explore the influences of the socio-economic factors affecting WTP and WTW using SPSS Statistics Version 20 (IBM Software, New York, NY, USA).

\section{Results}

\subsection{Respondents' Perceptions and Attitudes}

The socio-demographic characteristics of the respondents are presented in Table 3. There were more male (55.7\%), compared to female (46.3\%) respondents. The majority 
of respondents $(71.0 \%)$ were married and aged between 20 and 39 years $(73.1 \%)$. Most respondents $(70.7 \%)$ did not continue their education after graduating from secondary school. More than $80 \%$ of respondents earned less than $5000 \mathrm{CNY}$ per month. Their occupations were diverse, including businesspersons $(22.6 \%)$, farmers $(18.9 \%)$, and employees working for government and public institutions (17.5\%). Over half of the surveyed respondents $(60.4 \%)$ had resided in the communities for more than a decade. More than half of respondents $(54.5 \%)$ had a family size of $4-6$.

Table 3. Respondents' socio-demographic characteristics $(\mathrm{N}=1130)$.

\begin{tabular}{|c|c|c|}
\hline Item & Description & Frequency (\%) \\
\hline \multirow[t]{2}{*}{ Gender } & Male & $607(55.7)$ \\
\hline & Female & $523(46.3)$ \\
\hline \multirow[t]{5}{*}{ Age } & 20-29 years old & $507(44.9)$ \\
\hline & 30-39 years old & $319(28.2)$ \\
\hline & 40-49 years old & $183(16.2)$ \\
\hline & 50-59 years old & $91(8.1)$ \\
\hline & $>60$ years old & $30(2.7)$ \\
\hline \multirow[t]{2}{*}{ Marital status } & Married & $802(71.0)$ \\
\hline & Unmarried & $328(29.0)$ \\
\hline \multirow[t]{6}{*}{ Occupation } & Merchant & $255(22.6)$ \\
\hline & Farmer & $214(18.9)$ \\
\hline & $\begin{array}{l}\text { Employees of local government and } \\
\text { public institutions }\end{array}$ & 198 (17.5) \\
\hline & Service industry & $109(9.6)$ \\
\hline & Professional and technical staff & $106(9.4)$ \\
\hline & $\begin{array}{l}\text { Others (industry, student, freelancer, } \\
\text { retiree, unemployment, others) }\end{array}$ & $248(21.9)$ \\
\hline \multirow[t]{5}{*}{ Education level } & Junior middle school and below & $640(56.6)$ \\
\hline & Senior high school & $159(14.1)$ \\
\hline & Junior college & $151(13.4)$ \\
\hline & University undergraduate degree & $175(15.5)$ \\
\hline & Master's degree and above & $5(0.4)$ \\
\hline Monthly & $<3000 \mathrm{CNY}$ & $437(38.7)$ \\
\hline \multirow[t]{2}{*}{ income } & 3001-5000 CNY & $484(42.8)$ \\
\hline & >5001 CNY & $209(18.5)$ \\
\hline Residence & $1-10$ years & $448(39.6)$ \\
\hline duration & More than a decade & $682(60.4)$ \\
\hline \multirow[t]{4}{*}{ Family size } & $1-3$ individuals & $341(30.2)$ \\
\hline & 4-6 individuals & $616(54.5)$ \\
\hline & 7-9 individuals & $138(12.2)$ \\
\hline & $>10$ individuals & $35(3.1)$ \\
\hline
\end{tabular}

The vast majority of respondents (98.2\%) supported the establishment of NRs to protect ecosystems, and $94.8 \%$ of respondents were in favor of community involvement in conservation (Table 4$)$. However, most respondents $(81.2 \%)$ had no exposure to publicity or education regarding community-organized nature reserve ecosystem conservation programs. Almost 70\% of respondents agreed that the establishment of the NRs were of benefit to them, particularly in terms of providing better environmental and living conditions, as well as enhancing awareness of environmental-related issues. The majority of respondents reported having a deep connection with their community $(86.6 \%)$ and would like to reside in their community for a long time (75.2\%). In total, $92.4 \%$ of respondents supported the development of eco-tourism in nature reserves. Moreover, if necessary, more than half of respondents were willing to pay $(59.0 \%)$ or contribute time $(60.1 \%)$ to improving the protection of nature reserves. 
Table 4. Respondents' perceptions of nature reserves and their communities.

\begin{tabular}{|c|c|c|}
\hline Item & Description & Frequency $(\%)$ \\
\hline \multirow[t]{2}{*}{ I know the location of the nearby nature reserve. } & Yes & $625(55.3)$ \\
\hline & No & $505(44.7)$ \\
\hline \multirow[t]{2}{*}{ I know the ecological resources in the nature reserve. } & Yes & $436(38.6)$ \\
\hline & No & $694(61.4)$ \\
\hline \multirow{2}{*}{$\begin{array}{l}\text { I know there are institutes that conduct ecological resource } \\
\text { monitoring and protection in my neighborhood. }\end{array}$} & Yes & $561(49.6)$ \\
\hline & No & $569(50.4)$ \\
\hline \multirow{2}{*}{$\begin{array}{l}\text { I support the establishment of nature reserves to protect } \\
\text { ecological and environmental resources. }\end{array}$} & Yes & $1110(98.2)$ \\
\hline & No & $20(1.8)$ \\
\hline $\begin{array}{l}\text { I agree that the community should engage in conservation } \\
\text { programs that are }\end{array}$ & Yes & $1071(94.8)$ \\
\hline \multirow{2}{*}{$\begin{array}{l}\text { implemented by local government. } \\
\text { I have been exposed to publicity and education regarding } \\
\text { ecosystem }\end{array}$} & No & $59(5.2)$ \\
\hline & Yes & $212(18.8)$ \\
\hline $\begin{array}{l}\text { conservation in nature reserves that are organized by the } \\
\text { community. }\end{array}$ & No & $918(81.2)$ \\
\hline \multirow[t]{2}{*}{$\begin{array}{l}\text { The establishment of the nature reserve would be of } \\
\text { benefit to me. }\end{array}$} & Yes & $778(68.8)$ \\
\hline & No & $352(31.2)$ \\
\hline \multirow[t]{5}{*}{ I have a deep connection with the community. } & Very Dissatisfied & $13(1.2)$ \\
\hline & Dissatisfied & $3(0.3)$ \\
\hline & Indifferent & $135(11.9)$ \\
\hline & Satisfied & $356(31.5)$ \\
\hline & Very Satisfied & $623(55.1)$ \\
\hline \multirow[t]{5}{*}{ I would like to reside in this community for a long time. } & Very Dissatisfied & $21(1.9)$ \\
\hline & Dissatisfied & $94(8.3)$ \\
\hline & Indifferent & $165(14.6)$ \\
\hline & Satisfied & $262(23.2)$ \\
\hline & Very Satisfied & $588(52.0)$ \\
\hline \multirow{5}{*}{$\begin{array}{l}\text { I am willing to support the development of eco-tourism in } \\
\text { nature reserves. }\end{array}$} & Very Dissatisfied & $10(0.9)$ \\
\hline & Dissatisfied & $18(1.6)$ \\
\hline & Indifferent & $58(5.1)$ \\
\hline & Satisfied & $351(31.1)$ \\
\hline & Very Satisfied & $693(61.3)$ \\
\hline \multirow{5}{*}{$\begin{array}{l}\text { I think the ecological environment of nature reserves has } \\
\text { deteriorated } \\
\text { dramatically. }\end{array}$} & Very Dissatisfied & $72(6.4)$ \\
\hline & Dissatisfied & $530(46.9)$ \\
\hline & Indifferent & $180(15.9)$ \\
\hline & Satisfied & $277(24.5)$ \\
\hline & Very Satisfied & $71(6.3)$ \\
\hline \multirow{5}{*}{$\begin{array}{l}\text { If necessary, I am willing to pay money to improve the } \\
\text { protection of nature } \\
\text { reserves. }\end{array}$} & Very Dissatisfied & $120(10.6)$ \\
\hline & Dissatisfied & $122(10.8)$ \\
\hline & Indifferent & $222(19.6)$ \\
\hline & Satisfied & $585(51.8)$ \\
\hline & Very Satisfied & $81(7.2)$ \\
\hline \multirow{5}{*}{$\begin{array}{l}\text { If necessary, I am willing to spare time to improve the } \\
\text { protection of the } \\
\text { nature reserves. }\end{array}$} & Very Dissatisfied & 131 (11.6) \\
\hline & Dissatisfied & $113(10.0)$ \\
\hline & Indifferent & 207 (18.3) \\
\hline & Satisfied & $567(50.2)$ \\
\hline & Very Satisfied & $112(9.9)$ \\
\hline
\end{tabular}

\subsection{Respondents' Willingness to Participate}

A total of 659 (58.3\%) and 719 (63.6\%) respondents expressed their WTP and WTW for ecosystem conservation, respectively (Table 5). More respondents preferred to work than to pay for ecosystem conservation $(t=-2.50, \mathrm{df}=2256.75, p<0.05)$. The proportion of 
respondents willing to participate decreased with increasing cost, both in terms of money and time.

Nearly $42 \%$ of respondents chose the not-to-pay option. More than half of these $(58.4 \%)$ were unable to afford it. Almost half of the respondents (47.2\%) agreed that nature resource management and preservation should be spearheaded by the government.

Furthermore, over one-third of respondents $(36.4 \%)$ chose the not-to-work option. Of these, $62.8 \%$ were not willing to work, generally due to time constraints, while $28.5 \%$ considered ecosystem management and maintenance to be the responsibility of local and central governments.

Table 5. Respondents' bidding results.

\begin{tabular}{|c|c|c|c|c|c|c|}
\hline $\begin{array}{c}\text { Item } \\
\text { (Per person) }\end{array}$ & $\begin{array}{c}\text { First Bids } \\
\text { (Second Bids) }\end{array}$ & Frequency & $Y Y(\%){ }^{b}$ & $\mathrm{YN}(\%)^{\mathrm{c}}$ & NY (\%) ${ }^{d}$ & NN (\%) ${ }^{e}$ \\
\hline \multirow{4}{*}{$\begin{array}{c}\text { WTP } \\
\text { (CNY/year) }\end{array}$} & $\begin{array}{c}75^{\mathrm{a}} \\
(37.5 / 150)\end{array}$ & 283 & 32.5 & 22.3 & 10.2 & 35.0 \\
\hline & $\begin{array}{c}160 \\
(80 / 320)\end{array}$ & 282 & 18.4 & 30.1 & 17.7 & 33.7 \\
\hline & $\begin{array}{c}500 \\
(250 / 1000)\end{array}$ & 281 & 6.4 & 22.1 & 30.6 & 40.9 \\
\hline & $\begin{array}{c}750 \\
(375 / 1500)\end{array}$ & 284 & 7.0 & 12.7 & 23.2 & 57.0 \\
\hline \multirow{4}{*}{$\begin{array}{c}\text { WTW } \\
\text { (hours/month) }\end{array}$} & $\begin{array}{c}4 \\
(2 / 8)\end{array}$ & 282 & 55.0 & 8.9 & 5.3 & 30.9 \\
\hline & $\begin{array}{c}10 \\
(5 / 20)\end{array}$ & 284 & 41.5 & 16.9 & 7.4 & 34.2 \\
\hline & $\begin{array}{c}24 \\
(12 / 48)\end{array}$ & 285 & 27.4 & 26.7 & 8.1 & 37.9 \\
\hline & $\begin{array}{c}36 \\
(18 / 72)\end{array}$ & 279 & 15.1 & 30.8 & 11.5 & 42.7 \\
\hline
\end{tabular}

a First bid amounts, with second bid amounts in parentheses. If a respondent refused to pay the first bid amounts proposed, then we introduced the second bid amount, which was halved compared to the first bid amount. If a respondent agreed to pay the first bid amount, then we would increase the second bid amount. ${ }^{b}$ The percentage of respondents that agreed to pay the two bid amounts. ${ }^{c}$ The percentage of respondents who were unwilling to pay the first bid amount but agreed to pay the second bid amount. ${ }^{d}$ The percentage of respondents who agreed to pay the first bid amount but refused to pay the second bid amount. ${ }^{\mathrm{e}}$ The percentage of respondents who were completely unwilling to pay the two bid amounts.

\subsection{Willingness to Participate in Ecosystem Conservation}

The empirical results of the DBDC elicitation model are presented in Table 6. The models are significant at the $1 \%$ level, based on chi-square tests, indicating that they could be used to estimate the WTP and WTW for ecosystem conservation in southeastern Tibetan NRs.

The model results showed that income, education, acceptance to pay, and willingness to reside in the community significantly influenced WTP. At a $99 \%$ confidence interval, the coefficients of Lnincome, Edu, and ATP were positive, suggesting that respondents with a higher income, higher education, and greater acceptance toward paying, are more likely to pay higher amounts for ecosystem conservation. At a $95 \%$ significance level, Sense was also positive, suggesting that the stronger the resident's willingness to reside in the community, the more they were willing to pay.

Furthermore, income, education, and acceptance toward working significantly determined respondents' willingness to work for ecosystem conservation. The respondents' monthly income and acceptance toward working was found to be positively correlated, while education level was negative in the DBDC elicitation model. 
Table 6. Respondents' willingness to participate in ecosystem conservation.

\begin{tabular}{lllll}
\hline \multirow{2}{*}{ Variables } & WTP & & WTW & \\
\cline { 2 - 5 } & Coefficient & T Value & Coefficient & T Value \\
\hline Constant & 2.03 & $3.04^{* *}$ & 1.46 & $2.14^{*}$ \\
Lnincome & 0.26 & $3.63^{* *}$ & 0.22 & $2.89^{* *}$ \\
Know & 0.14 & 1.92 & 0.08 & 1.06 \\
Sense & 0.09 & $2.34^{*}$ & -0.008 & -0.19 \\
ATP & 0.29 & $4.50^{* *}$ & - & - \\
ATW & - & - & 0.24 & $4.26^{* *}$ \\
Marry & -0.13 & -1.44 & -0.07 & -0.78 \\
Edu & 0.05 & $3.13^{* *}$ & -0.03 & $-2.10^{*}$ \\
Group & 0.13 & 1.18 & -0.14 & -1.19 \\
Duration & -0.0007 & -0.26 & 0.0056 & 1.73 \\
Workp & -0.17 & -1.42 & 0.13 & 0.96 \\
Location1 & 0.17 & 1.66 & 0.04 & 0.38 \\
Location2 & 0.15 & 1.36 & 0.03 & 0.29 \\
Log likelihood & -922.26 & & -716.09 & \\
Log-likelihood ratio & $69.04 * *$ & & $41.46^{* *}$ & \\
$\chi_{(0.99,12)}^{2}$ & 26.22 & & 18.16 & \\
\hline * $p 0.05 ; * * p<0.01$. & & & &
\end{tabular}

\subsection{Willingness to Contribute According to Nature Reserve Type}

The median WTP and WTW were $369.1 \mathrm{CNY}$ per year and $38.7 \mathrm{~h}$ per month, respectively (Table 7). Only the WTP values differed significantly among different types of NRs. The WTP was greater for forestry NRs (394.3 CNY per year) than for wildlife NRs (320.6 CNY per year) and for wetland type NRs (355.1 CNY per year) $(p<0.01)$.

Table 7. Willingness to contribute to ecosystem conservation according to type of nature reserve.

\begin{tabular}{|c|c|c|c|c|c|c|}
\hline & $\begin{array}{l}\text { All } \\
\text { Samples } \\
(n=1130)\end{array}$ & $\begin{array}{l}\text { Wildlife } \\
(n=325)\end{array}$ & $\begin{array}{l}\text { Wetland } \\
\text { Ecosystem } \\
(n=214)\end{array}$ & $\begin{array}{l}\text { Forest } \\
\text { Ecosystem } \\
(n=591)\end{array}$ & F-Value & $p$ Value \\
\hline $\begin{array}{l}\text { WTP }^{a} \\
95 \% C I\end{array}$ & $\begin{array}{l}369.1 \\
(359.9, \\
378.3)\end{array}$ & $\begin{array}{l}320.6 \\
(310.0, \\
340.4)\end{array}$ & $\begin{array}{l}355.1 \\
(340.0, \\
367.0)\end{array}$ & $\begin{array}{l}394.3 \\
(381.0, \\
407.6)\end{array}$ & 19.78 & $<0.01$ \\
\hline $\begin{array}{l}\text { WTW }^{b} \\
95 \% C I\end{array}$ & $\begin{array}{l}38.7 \\
(38.0,39.4)\end{array}$ & $\begin{array}{l}37.1 \\
(35.6,38.6)\end{array}$ & $\begin{array}{l}38.7 \\
(37.5,39.9)\end{array}$ & $\begin{array}{l}39.3 \\
(38.3,40.3)\end{array}$ & 2.69 & ns \\
\hline
\end{tabular}

a CNY per person per year. ${ }^{\mathrm{b}}$ Working hours per person per month.

When comparing residents' community perceptions, the proportion of community residents participating in publicity and education in forest ecosystem NRs $(23.9 \%)$ was nearly twice compared to wetland type (12.1\%) and wildlife NRs (13.8\%). Moreover, in the communities near forestry NRs, nearly half of the residents (44.8\%) were aware that there was at least one protected ecological resource in the NRs.

\subsection{Influence of Socio-Economic Factors}

Variance analysis showed that the WTP values decreased with increasing age, family size, and residence duration (Figure 2). The WTP value was higher for unmarried residents and for males. The WTP value was generally high when respondents belonged to environmental groups and had education exposure and when they supported the establishment of nature reserves and supported community involvement in conservation actions. 

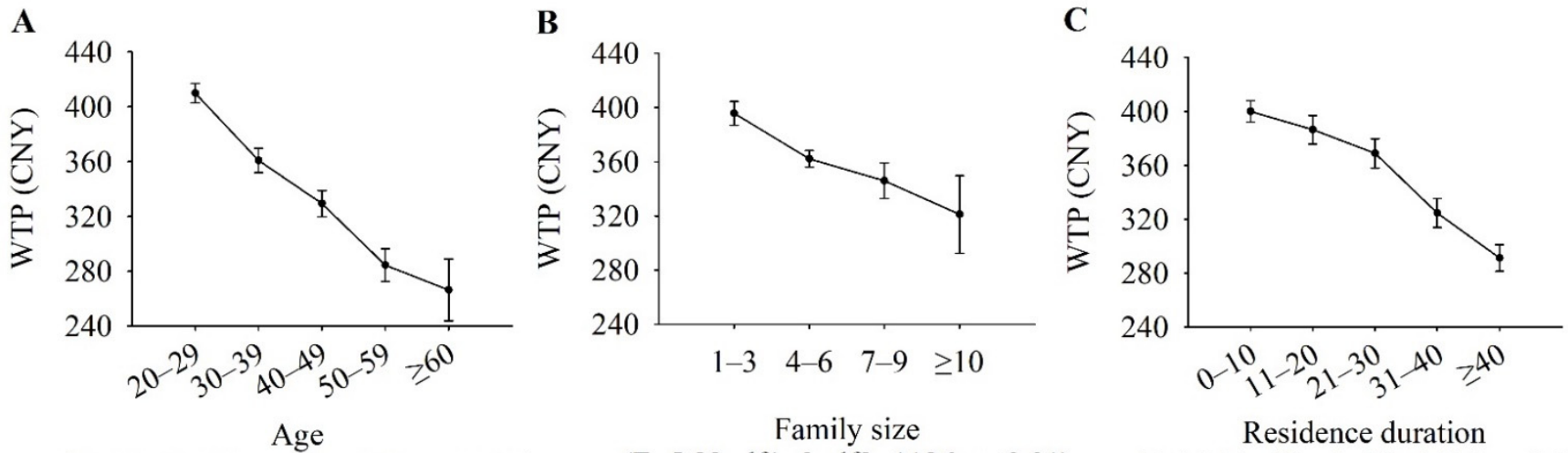

$(\mathrm{F}=23.23, \mathrm{dfl}=4, \mathrm{df} 2=1125, \mathrm{p}<0.01)$

Family size

$(\mathrm{F}=5.82, \mathrm{dfl}=3, \mathrm{df} 2=1126, \mathrm{p}<0.01)$

Residence duration

D

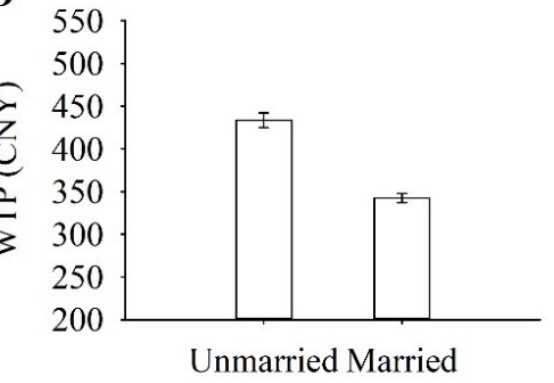

\section{E}
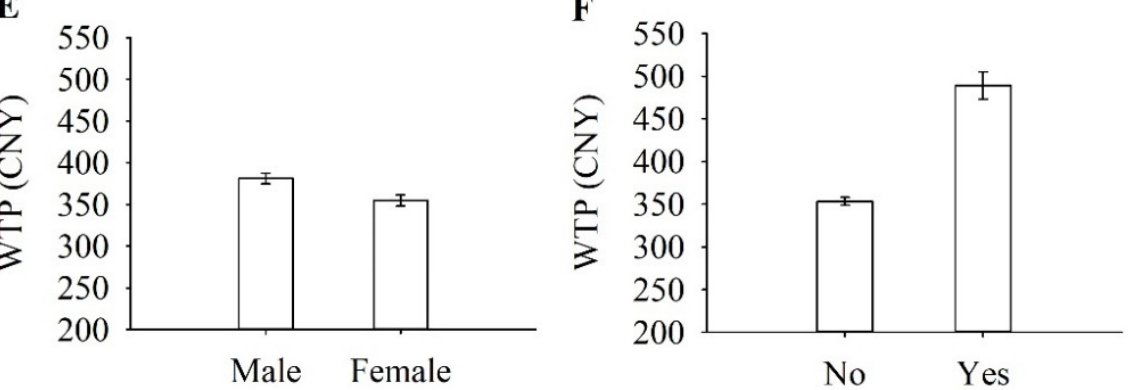

Marriage status $(\mathrm{t}=9.14, \mathrm{df}=1128, \mathrm{p}<0.01)$
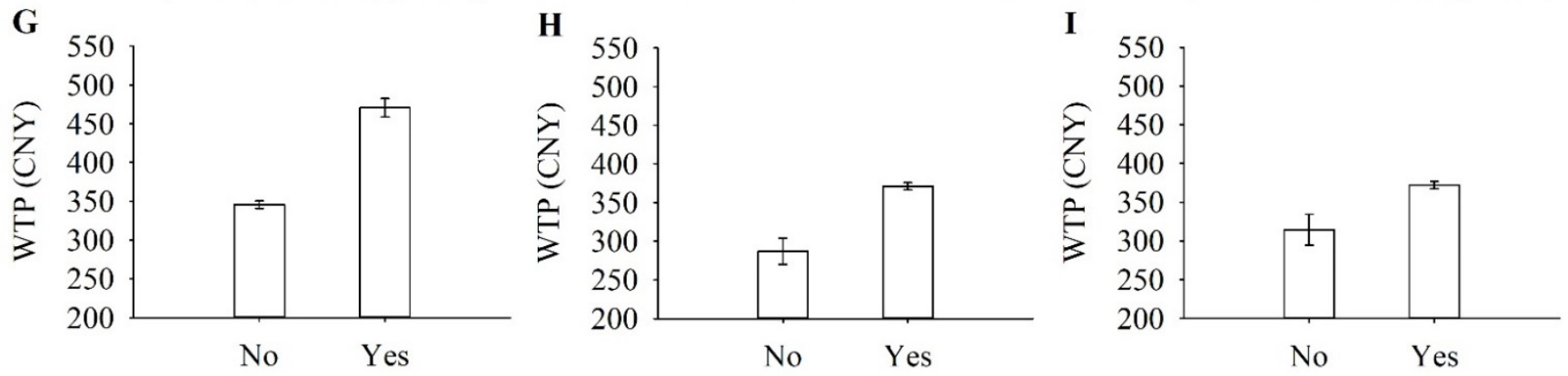

Participation in publicity and education $(\mathrm{t}=-9.74, \mathrm{df}=280.45, \mathrm{p}<0.01)$

Support to the establishment of NRs $(\mathrm{t}=-5.84, \mathrm{df}=22.11, \mathrm{p}<0.01)$

Support to community involvement $(\mathrm{t}=-2.76, \mathrm{df}=1128, \mathrm{p}<0.01)$

Figure 2. Respondents' WTP calculated by (A). Age group; (B). Family size; (C). Residence duration; (D). Marital status; (E). Gender; (F). Whether respondents belonged to an environmental group; (G). Exposure to publicity and education; $(\mathbf{H})$. Support for the establishment of nature reserves; and (I). Support for community involvement. The statistics in parentheses are the results of a one-way ANOVA or independent sample T test.

The WTW values increased with increasing family size and longer residence duration (Figure 3). Male respondents had a higher WTW value than females. The WTW values were also higher for residents who had relevant publicity and education exposure, belonged to environmental groups, and supported community participation. 
A

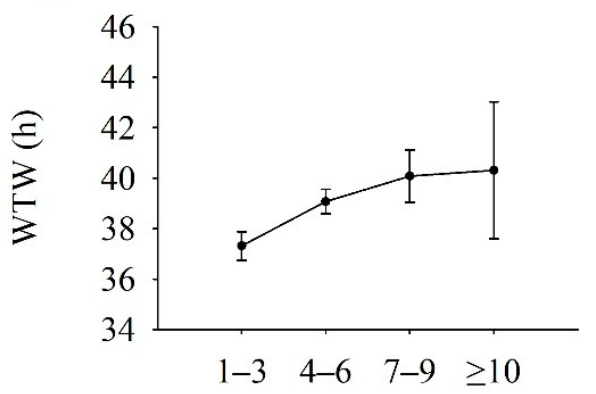

Family size

$(\mathrm{F}=2.66, \mathrm{df} 1=3, \mathrm{df} 2=1126, \mathrm{p}<0.01)$

D

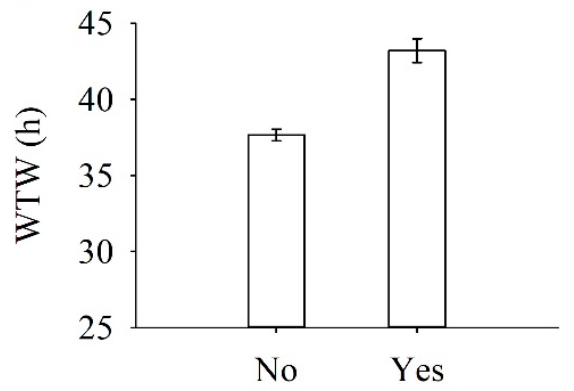

Participation in publicity and education $(\mathrm{t}=-6.30, \mathrm{df}=1128, \mathrm{p}<0.01)$
B

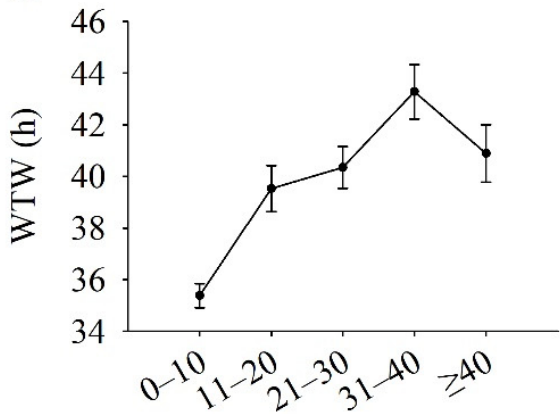

Residence duration

$(\mathrm{F}=18.07, \mathrm{df} 1=4, \mathrm{df} 2=1125, \mathrm{p}<0.01)$

E

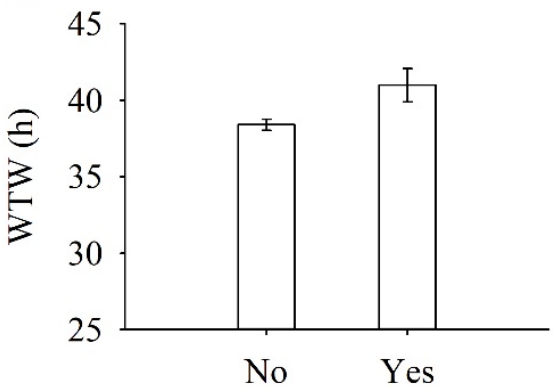

Belong to an environmental group $(t=-6.30, d f=1128, p<0.01)$
C

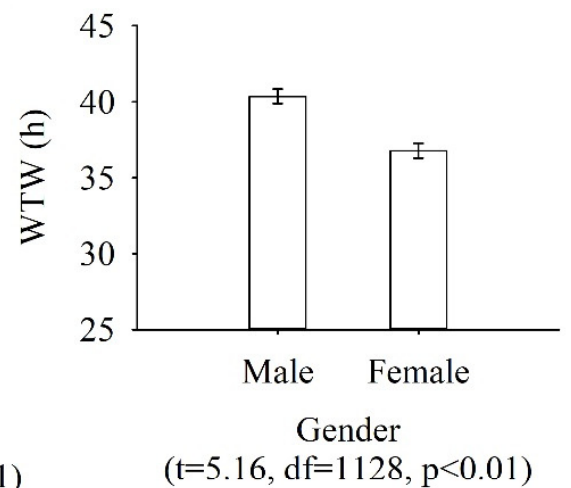

F

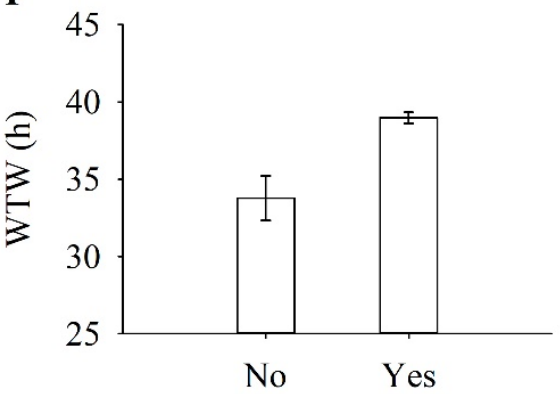

Support to community participation $(\mathrm{t}=-3.32, \mathrm{df}=1128, \mathrm{p}<0.01)$

Figure 3. Respondents' WTW calculated by (A). Family size; (B). Residence duration; (C). Gender; (D). Exposure to publicity and education; (E). Whether respondent belonged to an environmental group; and (F). Support for community participation. The statistics in parentheses are the results of a one-way ANOVA or independent sample $t$-test.

\section{Discussion}

\subsection{Factors Affecting Residents' Willingness to Participate in Ecosystem Conservation}

The community resident's willingness to participate in ecosystem conservation in NRs is determined by many factors, including the resident's socio-economic background and previous experience of involvement with conservation programs. We found that income, education, acceptance to pay, and willingness to reside in the community (for an extended period of time) affected WTP, while income, education, and acceptance to work were more likely to influence WTW (Table 6). Among the variables, annual income has emerged as the most widely acknowledged determining factor $[45,53]$. WTP depends primarily upon the respondents' income level, irrespective of the purposes of payment, and thus residents with higher incomes are likely to be willing to pay more for recreation or ecosystem conservation [46]. This was also found to be the case in our present study (Table 6). Income was also positively related to WTW for conservation. This may indicate that residents with higher incomes generally have better living conditions, and thus are more likely to contribute more time toward conservation actions [33].

Other socio-economic characteristics, such as gender, age, education, and marital status also play important roles. Male respondents had a higher preference for paying money and working for conservation efforts, compared with female respondents. This may be determined by social status or physiological differences $[47,54]$. Education had a positive impact on WTP but a negative impact on WTW (Table 6). In general, residents with higher education would likely have better awareness of environmental issues, and their higher incomes and quality of life level may also result in a higher WTP [47,55-57]. Generally, well-educated individuals are more likely to spend certain amounts of money to fund, rather than work for, ecosystem conservation [35]. Younger respondents were found 
to have higher WTP values than older respondents (Figure 2). Ecological conservation is becoming popular in China; hence, younger respondents are more likely to participate in conservation actions than seniors [51]. Similarly, unmarried respondents (who tended to be younger) had higher WTP values than married respondents (Figure 2). The reason might be that married residents typically have greater responsibility to support their families, and therefore less free time [58].

The residence situation of respondents in these localities needs to be analyzed synthetically. Residents who showed a strong willingness to live in their community were willing to pay more money to protect the ecosystem (Table 6) because they usually had a stronger sense of community attachment [59]. Family size and duration of residence were negatively related to WTP. In our study areas, the majority of respondents had a family size of $4-7(60.5 \%)$, and $81.5 \%$ of respondents earned less than 5000 CNY per month. On a perhousehold basis, larger families generally require greater expenditure on daily necessities, which limits their ability to pay for conservation efforts. Meanwhile, residents who had been living in their communities over an extended period were more willing to work for NRs (Figure 3). This indicates that the duration of people's residence in a locality can affect their decision-making in terms of the form their participation in ecosystem conservation will take. Specifically, long-term residents are more willing to engage in local conservation activities and services.

The community residents' acceptance of contributing money and labor were positively related to WTP and WTW (Table 6). This may be because a solid groundwork of awareness already existed - in terms of respondents being psychologically prepared to contributemaking them much more likely to accept donating higher monetary sums and devoting greater numbers of working hours [44,60]. Comparatively speaking, people's previous participation experience can change their attitudes toward environmental conservation. Respondents with ecological conservation experience (including joining an environmental organization and exposure to publicity and education) showed higher willingness to contribute to protective action than those who lacked such experience. Through public education, the former group of participants were well informed about the importance of ecosystem conservation. Their ecological awareness promoted their understanding of ecosystem functions and services, which, in turn, led to a greater willingness to participate in environmental protection programs [51]. This suggests that the emphasis for community outreach education in the future should be on increasing residents' knowledge and awareness of local ecosystems and their special service functions. Many successful attempts have been made worldwide to implement community-based conservation that includes biodiversity and ecosystem protection [61]. For instance, a study on Zimbabwe's CAMPFIRE programs concluded that involving residents in wildlife management could be highly effective for the restoration of local wildlife populations and habitats [62]. In another study, the number of Bengal tigers in an Indian national park increased as the communities in and around the park became more involved in conservation efforts, including measures such as forming patrols to detect poachers [63]. A comparison of existing studies that have delivered the desired protection results revealed that community participation is an important predictor of success in ecosystem conservation [61]. Estimating the locals willingness to participate is a promising avenue for smoothing the path to effective implementation of management plans [64]. Therefore, the findings of the present study can provide policymakers with a useful model for the management of other similar nature reserves in the Qinghai-Tibet plateau region, as well as greater China, and can be used as an indicator for determining payments for ecosystem services, which can help in ensuring the sustainable utilization of Tibet's natural resources.

\subsection{Willingness to Participate According to NR Type}

In a comparison of the three types of NRs, we found that the WTP value was the highest for forest ecosystem NRs in southeast Tibet (Table 7). This may be due in a large part to the ecosystem services provided by forests. Forests provide an especially large 
quantity of provisioning, regulating, supporting, and cultural ecosystem services for local communities, which invariably means they play a multi-dimensional role in the wellbeing of humans $[1,25,65,66]$. Specifically, due to the special geological conditions there, collapses, landslides, and debris flows occur frequently in Tibet [67]. The importance of forests in soil and water conservation, wind prevention, and sand fixation is therefore obvious [68-70]. Since the major regions in southeast Tibet are covered by forests [71], local residents can directly benefit from healthy forests and are more likely to participate in conservation actions.

Furthermore, a second reason for such high WTP values in connection to forest ecosystem NRs is likely that local community residents are increasingly aware of the importance of protecting forest ecosystems. The Chinese government has launched several large ecological restoration programs in southeast Tibet since the late 1990s, such as the Grain for Green Program, the Natural Forest Protection Program, and the Forest Ecological Compensation Program, and it has set up professional management and protection teams to protect non-commercial forests $[72,73]$. In order to enhance the effectiveness of forest conservation, local governments encourage community residents to collaborate with staff working in nature reserves to participate in numerous conservation programs. Local residents can be employed by the government to patrol non-commercial forests regularly, as well as to participate in afforestation programs that usually last up to one month. These types of programs and policies not only preserve the remaining forests and increase vegetation productivity, but also increase residents' awareness of conserving forests [74,75].

\subsection{The Willingness of Tibetan Communities to Participate in Ecosystem Conservation}

The importance of community participation in conservation management approaches has been widely recognized by various research institutions, environmental groups, and non-governmental organizations working in the conservation field [16]. The greatest advantage of local community involvement in conservation lies in reducing protection costs effectively in terms of both time and financial outlay, since such involvement reduces the requirement for outside technical expertise and human resources [76]. The level of investment in ecosystem conservation is huge in China. According to government statistics, the Central Finance authorities allocated 1.7 billion CNY in forestry subsidies to the Tibet Autonomous Region in 2016, and this amount has been increasing annually [77]. In this study, in order to protect the ecosystem from degradation, the median WTP and WTW of individuals were found to be 369.1 CNY per year and $38.7 \mathrm{~h}$ per month, respectively. Given Tibet's population of 3,648,100 (Seventh National Census data), the total WTP and WTW of the whole region would be 1.3 billion CNY and 71 million days, per year, respectively. Therefore, the potential for contribution toward ecosystem conservation in Tibet is enormous, from both financial and workforce perspectives. Including local communities in nature reserve management not only can reduce the government's economic burden but can also stimulate awareness and the visibility of conservation actions in local communities, and thus help maximize ecosystem services. The majority of local residents surveyed preferred to work for ecosystem conservation instead of paying for it (Table 4). This suggests that WTW is acceptable as a proxy of willingness to participate. The percentage of residents who were unwilling to participate in conservation increased with increasing amounts of payments and number of working hours. The main reason for the unwillingness to pay or being reluctant to work was lack of financial capacity or time, and the majority of residents who were unwilling to pay or devote working hours still insisted that conservation actions should be undertaken by the local government. These results are consistent with previous studies $[23,45,78]$, suggesting that residents still expect governments to lead in conservation actions though recognizing the importance of ecosystem conservation.

In southeast Tibet, the application of WTW in evaluating willingness to participate has been proven to be valid. This suggests that the use of multiple payment vehicles is particularly important. For example, Casiwan-Launio et al. investigated local residents 
WTP and WTW for the continued existence of the San Miguel Island (SMI) fishery reserve and found that WTW can be used as an eliciting method for stated preference studies in rural developing islands [33]. Ballad et al. confirmed that local residents were willing to voluntarily provide labor to maintain the ecological balance of the coastal and marine resources when their income was constrained [79]. Tilahun et al. assessed rural households WTP and WTW for frankincense forest conservation and found that respondents were willing to contribute more in labor than in money in a low-income country [27]. However, labor or working time contributions cannot replace cash payments completely because of inadequate coverage of requirements when labor is used as a payment vehicle, and the potential difference in the availability of cash or labor [32].

\section{Conclusions}

Local communities can contribute substantially to ecosystem conservation. In places where residents have a high willingness to participate, NRs can organize relevant voluntary activities to allow community residents to play a positive role in conservation actions, thus assisting in NR management. Meanwhile, our study found that community residents living in or adjacent to forest ecosystem NRs have the highest WTP, indicating that the current forest protection policy is effective. This suggests that local governments should provide additional environmental education activities to gradually raise the conservation awareness of community residents. For the community residents in southeast Tibet, labor contribution is much more acceptable, feasible, and practical than making monetary contributions, so voluntary activities can be systematically incorporated into ecosystem conservation. Residents with different socio-economic characteristics have different levels of willingness to participate in ecosystem conservation. This suggests that individual-level characteristics affect residents' conservation awareness. Such information is critical when decision makers are challenged with multiple conservation priorities and can help to ensure that the bestsuited community residents are chosen to participate in conservation projects.

Supplementary Materials: The following supporting information can be downloaded at https: //www.mdpi.com/article/10.3390/land11020207/s1.

Author Contributions: Conceptualization, L.X., W.X., K.C., C.-H.L., C.Z. and J.M.; Methodology, L.X., C.J., H.D., K.C., C.-H.L. and C.Z.; Investigation, L.X., H.D. and C.Z.; Data curation, C.J.; Formal analysis, L.X., K.C. and C.-H.L.; Writing-original draft preparation, L.X.; Writing-review and editing, Q.S., K.C. and C.-H.L.; Visualization, L.X.; Funding acquisition, K.C. and C.Z. All authors have read and agreed to the published version of the manuscript.

Funding: This research was funded by the Fundamental Research Funds for the Central Universities of China (Grant No. 2572020DZ11; Grant No. 2572020DR11) and the National Natural Science Foundation of China (Grant No. 31772469).

Institutional Review Board Statement: Not applicable.

Informed Consent Statement: Informed consent was obtained from all subjects involved in the study.

Data Availability Statement: Not applicable.

Conflicts of Interest: The authors declare no conflict of interest.

\section{References}

1. Millennium Ecosystem Assessment (MA). Ecosystems and Human Well-Being: A Framework for Assessment; Island Press: Washington, DC, USA, 2003.

2. Li, S.; Zhang, H.; Zhou, X.; Yu, H.; Li, W. Enhancing protected areas for biodiversity and ecosystem services in the Qinghai-Tibet Plateau. Ecosyst. Serv. 2020, 43, 101090. [CrossRef]

3. Ma, B.; Zhang, Y.; Huang, Y.; Wen, Y. Socioeconomic and ecological direct and spillover effects of China's giant panda nature reserves. For. Policy Econ. 2020, 121, 102313. [CrossRef]

4. Chen, G.; Zhang, R.; Guo, X.; Wu, W.; Guo, Q.; Zhang, Y.; Yan, B. Comparative evaluation on municipal sewage sludge utilization processes for sustainable management in Tibet. Sci. Total Environ. 2021, 765, 142676. [CrossRef] [PubMed] 
5. Ouyang, Z.; Du, A.; Xu, W. Research on China's protected area system classification. Acta Ecol. Sin. 2020, 40, 7207-7215. [CrossRef]

6. Wang, W.; Li, J. In-situ conservation of biodiversity in China: Advances and prospects. Biodivers. Sci. 2021, 29, 133-149. [CrossRef]

7. Jiang, W.; Lü, Y.; Liu, Y.; Gao, W. Ecosystem service value of the Qinghai-Tibet Plateau significantly increased during 25 years. Ecosyst. Serv. 2020, 44, 101146. [CrossRef]

8. Dong, H.; Feng, Z.; Yang, Y.; Li, P.; You, Z. Dynamic assessment of ecological sustainability and the associated driving factors in Tibet and its cities. Sci. Total Environ. 2021, 759, 143552. [CrossRef]

9. Li, S.; Wu, J.; Gong, J.; Li, S. Human footprint in Tibet: Assessing the spatial layout and effectiveness of nature reserves. Sci. Total Environ. 2018, 621, 18-29. [CrossRef]

10. Zheng, Y.; Hou, X. The Practice and Experience of the Communist Party of China in the Construction of Tibetan Ecological Civilization since Reform and Opening-up. J. Southwest Minzu Univ. (Hum. Soc. Sci.) 2022, 43, 182-191.

11. Feng, C.; Cao, M.; Wang, W.; Wang, H.; Liu, F.; Zhang, L.; Du, J.; Zhou, Y.; Huang, W.; Li, J. Which management measures lead to better performance of China's protected areas in reducing forest loss? Sci. Total Environ. 2020, 764, 142895. [CrossRef]

12. Ivanova, I.M.; Cook, C.N. The role of privately protected areas in achieving biodiversity representation within a national protected area network. Conserv. Sci. Pract. 2020, 2, e307. [CrossRef]

13. Pan, Y.; Wu, J.; Zhang, Y.; Zhang, X.; Yu, C. Simultaneous enhancement of ecosystem services and poverty reduction through adjustments to subsidy policies relating to grassland use in Tibet, China. Ecosyst. Serv. 2021, 48, 101254. [CrossRef]

14. Hasan, E.; Bahauddin, K.M. Community's Perception and Involvement in Co-management of Bhawal National Park, Bangladesh. J. Nat. Sci. Res. 2014, 4, 60-67.

15. Amadu, M.; Ayamga, M.; Mabe, F.N. Assessing the value of forest resources to rural households: A case of forest-fringe communities in the Northern Region of Ghana. Environ. Dev. 2021, 37, 100577. [CrossRef]

16. Sagoe, A.A.; Aheto, D.W.; Okyere, I.; Adade, R.; Odoi, J. Community participation in assessment of fisheries related ecosystem services towards the establishment of marine protected area in the Greater Cape Three Points area in Ghana. Mar. Pol. 2021, 124, 104336. [CrossRef]

17. Störmer, N.; Weaver, L.C.; Stuart-Hill, G.; Diggle, R.W.; Naidoo, R. Investigating the effects of community-based conservation on attitudes towards wildlife in Namibia. Biol. Conserv. 2019, 233, 193-200. [CrossRef]

18. Sinthumule, N.I. An analysis of communities' attitudes towards wetlands and implications for sustainability. Glob. Ecol. Conserv. 2021, 27, e01604. [CrossRef]

19. Haensch, J.; Wheeler, S.A.; McWhinnie, S. Community attitudes towards marine parks in South Australia. Mar. Pol. 2020, 104121. [CrossRef]

20. Bunclark, L.; Carter, R.; Casey, V.; Day, S.J.; Guthrie, D. Managing Water Locally: An Essential Dimension of Community Water Development; Institution of Civil Engineers: London, UK, 2011.

21. Abukari, H.; Mwalyosi, R.B. Comparing pressures on national parks in Ghana and Tanzania: The case of Mole and Tarangire national parks. Glob. Ecol. Conserv. 2018, 15, e00405. [CrossRef]

22. Zhao, F.; Huang, M. Exploring the Non-Use Value of Important Agricultural Heritage System: Case of Lingnan Litchi Cultivation System (Zengcheng) in Guangdong, China. Sustainability 2020, 12, 3638. [CrossRef]

23. Liu, J.; Liu, N.; Zhang, Y.; Qu, Z.; Yu, J. Evaluation of the non-use value of beach tourism resources: A case study of Qingdao coastal scenic area, China. Ocean Coastal Manage. 2019, 168, 63-71. [CrossRef]

24. Gibson, J.M.; Rigby, D.; Polya, D.A.; Russell, N. Discrete Choice Experiments in Developing Countries: Willingness to Pay Versus Willingness to Work. Environ. Resour. Econ. 2016, 65, 697-721. [CrossRef]

25. Huang, C.-H.; Lee, C. Consumer willingness to pay for organic fresh milk in Taiwan. China Agric. Econ. Rev. 2014, 6, 198-211. [CrossRef]

26. Chu, X.; Zhan, J.; Wang, C.; Hameeda, S.; Wang, X. Households' Willingness to Accept Improved Ecosystem Services and Influencing Factors: Application of Contingent Valuation Method in Bashang Plateau, Hebei Province, China. J. Environ. Manage. 2020, 255, 109925. [CrossRef] [PubMed]

27. Tilahun, M.; Vranken, L.; Muys, B.; Deckers, J.; Gebregziabher, K.; Gebrehiwot, K.; Bauer, H.; Mathijs, E. Rural Households' demand for frankincense forest conservation in Tigray, Ethiopia: A contingent valuation analysis. Land Degrad. Dev. 2015, 26, 642-653. [CrossRef]

28. Michael, A.; Oliver, F.; Antonia, H.; Duc, N.M.; Dinh, P.V. Labour as a Utility Measure in Contingent Valuation Studies: How Good is it Really? FZID Discussion Paper; Universität Hohenheim, Forschungszentrum Innovation und Dienstleistung (FZID): Stuttgart, Germany, 2010.

29. Schiappacasse, I.; Vásquez, F.; Nahuelhual, L.; Echeverría, C. Labor as a welfare measure in contingent valuation: The value of a forest restoration project. Cienc. Investig. Agrar. 2013, 40, 69-84. [CrossRef]

30. Solikin, A. Willingness to Pay and Willingness to Work to Avoid Deforestation and Forest Degradation; ICoSI 2014; Springer: Singapore, 2017. [CrossRef]

31. Swallow, B.M.; Woudyalew, M. Evaluating willingness to contribute to a local public good: Application of contingent valuation to tsetse control in Ethiopia. Ecol. Econ. 1994, 11, 153-161. [CrossRef]

32. Kassahuna, H.T.; Jacobsen, J.B.; Nicholson, C.F. Revisiting chut and land labor for valuing environmental goods and services in developing countries. Ecol. Econ. 2020, 177, 106771. [CrossRef] 
33. Casiwan-Launio, C.; Shinbo, T.; Morooka, Y. Island Villagers' Willingness to Work or Pay for Sustainability of a Marine Fishery Reserve: Case of San Miguel Island, Philippines. Coast. Manage. 2011, 39, 459-477. [CrossRef]

34. Rai, R.K.; Scarborough, H. Nonmarket valuation in developing countries: Incorporating labour contributions in environmental benefits estimates. Aust. J. Agr. Resour. Econ. 2014, 59, 479-498. [CrossRef]

35. Zhang, J.; Shen, X.; Wang, B. Changes in precipitation extremes in Southeastern Tibet, China. Quat. Int. 2015, 380-381, 49-59. [CrossRef]

36. Xue, D.; Jiang, M. A Study on Categoring Standard of Nature Reserves in China. China Environ. Sci. 1994, 14, $246-251$.

37. Bhandari, A.K.; Heshmati, A. Willingness to Pay for Biodiversity Conservation. J. Travel Tour. Mark. 2010, 27, 612-623. [CrossRef]

38. Reynisdottir, M.; Song, H.; Agrusa, J. Willingness to pay entrance fee to natural attractions: An Icelandic case study. Tour. Manage. 2008, 29, 1076-1083. [CrossRef]

39. Alberini, A. Testing willingness-to-pay models of discrete choice contingent valuation survey data. Land Econ. 1995, 71, 83-95. [CrossRef]

40. Huang, C.-H.; Wang, C.-H. Estimating the Total Economic Value of Cultivated Flower Land in Taiwan. Sustainability 2015, 7, 4764-4782. [CrossRef]

41. Cranford, M.; Mourato, S. Community conservation and a two-stage approach to payments for ecosystem services. Ecol. Econ. 2011, 71, 89-98. [CrossRef]

42. Alberini, A. Optimal Designs for Discrete Choice Contingent Valuation Surveys: Single-Bound, Double-Bound, and Bivariate Models. J. Environ. Econ. Manage. 1995, 28, 287-306. [CrossRef]

43. Lawless, J.F. Statistical Models and Methods for Lifetime Data; John Wiley \& Sons: Hoboken, NJ, USA, 2011.

44. Vásquez, W.F. Willingness to pay and willingness to work for improvements of municipal and community-managed water services. Water Resour. Res. 2014, 50, 8002-8014. [CrossRef]

45. Dai, H.; Lee, C.-H.; Cheng, K.; Zong, C. Community Residents' Willingness to Contribute to Wetland Ecosystem Services in Sanjiang Plain Nature Reserves. J. Nat. Resour. 2017, 32, 977-987. [CrossRef]

46. Adamu, A.; Yacob, M.R.; Hashim, R. Factors Determining Visitors' Willingness to Pay for Conservation in Yankari Game Reserve, Bauchi, Nigeria. Int. J. Econ. Manage. 2015, 9, 95-114.

47. Grazhdani, D. Estimating residents' willing to pay using contingent valuation for ecological restoration and recreational benefits of AL-Prespa protected area in Albania. J. Food Agric. Environ. 2014, 12, 365-370. [CrossRef]

48. Chen, H.-C.; Tseng, T.-P.; Cheng, K.; Sriarkarin, S.; Xu, W.; Ferdin, A.E.J.; Nguyen, V.V.; Zong, C.; Lee, C.-H. Conducting an Evaluation Framework of Importance-Performance Analysis for Sustainable Forest Management in a Rural Area. Forests 2021, 12, 1357. [CrossRef]

49. Nguyen, V.V.; Phan, T.T.T.; Ferdin, A.E.J.; Lee, C.-H. Conducting Importance-Performance Analysis for Human-Elephant Conflict Management Surrounding a National Park in Vietnam. Forests 2021, 12, 1458. [CrossRef]

50. Lee, C.-H.; Chen, H.-S.; Liou, G.-B.; Tsai, B.-K.; Hsieh, C.-M. Evaluating International Tourists' Perceptions on Cultural Distance and Recreation Demand. Sustainability 2018, 10, 4360. [CrossRef]

51. Loomis, J.; Lockwood, M.; DeLacy, T. Some Empirical Evidence on Embedding Effects in Contingent Valuation of Forest Protection. J. Environ. Econ. Manage. 1993, 25, 45-55. [CrossRef]

52. Cooper, J.C.; Hanemann, M.; Signorello, G. One-and-One-Half-Bound Dichotomous Choice Contingent Valuation. Rev. Econ. Statistics 2002, 84, 742-750. [CrossRef]

53. More, T.; Stevens, T. Do user fees exclude low-income people from resource-based recreation? J. Leis. Res. 2017, 32, 341-357. [CrossRef]

54. Kamri, T.; Ali, J.K.; Harun, N.F.A. Willingness To Pay For Conservation of Natural Resources in Santubong National Park. Manaj. Dan Kewirausahaan 2017, 19, 16-21. [CrossRef]

55. Brennan, D.; Tapsuwan, S.; Ingram, G. The welfare costs of urban outdoor water restrictions. Aust. J. Agr. Resour. Econ. 2007, 51, 243-261. [CrossRef]

56. Li, X.; Cai, Y. Empirical Analysis of the Relationship between Quality Comparable Educationand Resident Income-Research Based on CGSS Data. J. Statistics 2020, 1, 85-94. [CrossRef]

57. Gradín, C.; Wu, B. Income and consumption inequality in China: A comparative approach with India. China Econ. Rev. 2020, 62, 101463. [CrossRef]

58. Burgoyne, C.B.; Reibstein, J.; Edmunds, A.; Dolman, V. Money management systems in early marriage: Factors influencing change and stability. J. Econ. Psychol. 2007, 28, 214-228. [CrossRef]

59. Peng, W.; López-Carr, D.; Wu, C.; Wang, X.; Longcore, T. What factors influence the willingness of protected area communities to relocate? China's ecological relocation policy for Dashanbao Protected Area. Sci. Total Environ. 2020, 727, 138364. [CrossRef] [PubMed]

60. Gao, Q.; Ao, C.; Chen, H.; Tong, R. Spatial differentiation research of non-use value WTP based on the residents'ecological cognition: Taking the Sanjiang Plain as a case. Acta Ecol. Sin. 2014, 34, 1851-1859. [CrossRef]

61. Zhang, Y.; Xiao, X.; Cao, R.; Zheng, C.; Guo, Y.; Gong, W.; Wei, Z. How important is community participation to eco-environmental conservation in protected areas? From the perspective of predicting locals' pro-environmental behaviours. Sci. Total Environ. 2020, 739, 139889. [CrossRef] 
62. Taylor, R. Community based natural resource management in Zimbabwe: The experience of CAMPFIRE. Biodivers. Conserv. 2009, 18, 2563-2583. [CrossRef]

63. Zhang, S.; Wang, M.; Wang, Z. Experience and Enlightenments of Indian National Park CommunitiesParticipating in Tiger Conservation. J. Beijing For. Univ. (Soc. Sci.) 2021, 2, 101-107. [CrossRef]

64. Bhat, M.Y.; Sofi, A.A. Willingness to pay for biodiversity conservation in Dachigam National Park, India. J. Nat. Conserv. 2021, 62, 126022. [CrossRef]

65. Mikusińskia, G.; Niedziałkowski, K. Perceived importance of ecosystem services in the Białowieża Forest for local communities Does proximity matter? Land Use Pol. 2020, 97, 104667. [CrossRef]

66. Daily, G.C.; Alexander, S.; Ehrlich, P.R.; Goulder, L.; Lubchenco, J.; Matson, P.; Mooney, H.A.; Postel, S.; Schneider, S.; Tilman, D. Ecosystem services: Benefits supplied to human societies by natural ecosystems. Issues Ecol. 1997, 1, 1-16.

67. Yu, G.-A.; Lu, J.; Lyu, L.; Han, L.; Wang, Z. Massflows and river response in rapid uplifting regions-A case of lower Yarlung Tsangpo basin, southeast Tibet, China. Int. J. Sediment Res. 2020, 35, 609-620. [CrossRef]

68. Ahammad, R.; Stacey, N.; Sunderland, T.C.H. Use and perceived importance of forest ecosystem services in rural livelihoods of Chittagong Hill Tracts, Bangladesh. Ecosyst. Serv. 2019, 35, 87-98. [CrossRef]

69. Foli, S.; Reed, J.; Clendenning, J.; Petrokofsky, G.; Padoch, C.; Sunderland, T. To what extent does the presence of forests and trees contribute to food production in humid and dry forest landscapes?: A systematic review protocol. Environ. Evid. $2014,3,15$. [CrossRef]

70. Reed, J.; Vianen, J.; Foli, S.; Clendenning, J.; Yang, K.; MacDonald, M.; Petrokofsky, G.; Padoch, C.; Terry, S. Trees for life: The ecosystem service contribution of trees to food production and livelihoods in the tropics. For. Policy Econ. 2017, 84, 62-71. [CrossRef]

71. Ge, L.; Pan, G.; Ren, D.; Du, Y.; Zheng, X. Forest carbon storage, carbon density, and their distribution characteristics in Linzhi area of Tibet, China. Chin. J. Appl. Ecol. 2013, 24, 319-325. [CrossRef]

72. Sun, Y.; Liu, S.; Shi, F.; An, Y.; Li, M.; Liu, Y. Spatio-temporal variations and coupling of human activity intensity and ecosystem services based on the four-quadrant model on the Qinghai-Tibet Plateau. Sci. Total Environ. 2020, 743, 140721. [CrossRef]

73. Ge, R.; Xu, K.; Wang, X.; Wang, J. Water erosion in the middle reaches of the Brahmaputra in Tibet: Characteristics and driving factors in the recent 30 years. Glob. Ecol. Conserv. 2020, 24, e01343. [CrossRef]

74. Ren, G.; Young, S.S.; Wang, L.; Wang, W.; Long, Y.; Wu, R.; Li, J.; Zhu, J.; Yu, D.W. Effectiveness of China's National Forest Protection Program and nature reserves. Conserv. Biol. 2015, 29, 1368-1377. [CrossRef]

75. Zhao, H.; Wu, R.; Long, Y.; Hu, J.; Yang, F.; Jin, T.; Wang, J.; Hu, P.; Wu, W.; Diao, Y.; et al. Individual-level performance of nature reserves in forest protection and the effects of management level and establishment age. Biol. Conserv. 2019, 233, 23-30. [CrossRef]

76. Pagdee, A.; Kawasaki, J. The importance of community perceptions and capacity building in payment for ecosystems services: A case study at Phu Kao, Thailand. Ecosyst. Serv. 2021, 47, 101224. [CrossRef]

77. Management Measures of National Fund for Ecological Protection and Restoration of Forests and Grasslands. Available online: http:/ / www.forestry.gov.cn/html/main/main_195/20200508081428606643022/file/20200508081728526627509.pdf (accessed on 14 December 2021).

78. Wang, P.-W.; Jia, J.-B. Tourists' willingness to pay for biodiversity conservation and environment protection, Dalai Lake protected area: Implications for entrance fee and sustainable management. Ocean Coastal Manage. 2012, 62, 24-33. [CrossRef]

79. Ballad, E.L.; Shinbo, T.; Morooka, Y. Evaluation of the Villagers' Willingness to Work or Pay for the Promotion of Community-based Marine Protected Areas in Cagayan Province, Philippines. JPN J. Agric. Econ. 2018, 20, 61-66. [CrossRef] 